\title{
Reproductive System Findings Sequence Number
}

National Cancer Institute

\section{Source}

National Cancer Institute. Reproductive System Findings Sequence Number. NCI

Thesaurus. Code C117636.

An identifier that describes the relative position of reproductive system findings data within a series. 